\title{
Ras-Related Protein Rab-12
}

National Cancer Institute

\section{Source}

National Cancer Institute. Ras-Related Protein Rab-12. NCI Thesaurus. Code C142756.

Ras-related protein Rab-12 (244 aa, $\sim 27 \mathrm{kDa}$ ) is encoded by the human RAB12 gene.

This protein is involved in the regulation of trafficking of intracellular vesicles. 